\title{
DIEL PATTERNS OF SUSPENDED SEDIMENT FLUX AND THE ZOOGEOMORPHIC AGENCY OF INVASIVE CRAYFISH
}

\author{
S.P. RICE ${ }^{1 *}$, M.F. JOHNSON ${ }^{1}$, C. EXTENCE ${ }^{2}$, J. REEDS ${ }^{2}$, H. LONGSTAFF ${ }^{2}$ \\ ${ }^{1}$ Department of Geography, Loughborough University, United Kingdom. \\ ${ }^{2}$ Environment Agency, United Kingdom.
}

\begin{abstract}
The role of biotic forcing in fluvial geomorphology is understudied. This paper investigates the suggestion that the activities of signal crayfish (Pacifastacus leniusculus) can increase suspended sediment fluxes in rivers. Previous field work, supported by mesocosm experiments, suggests that crayfish nocturnalism can cause night time increases in turbidity, but field data are limited to a 16-hour period from a single site where suspended sediment time-series are not available. Here, field data collected over a 28-day period on the Brampton Branch of the River Nene, $U K$, are used to quantify the impact of diel fluctuations in suspended sediment concentration on sediment fluxes. Field observations and laboratory experiments are used to evaluate the likelihood that crayfish, which are abundant in this river, are responsible for the diel patterns. Turbidity and water stage were measured at 2-minute intervals at a single site. Water was sampled for suspended sediment concentration on a diel cycle and during storm events. A relation between suspended sediment concentration and turbidity, along with a local discharge time-series, permitted calculation of sediment flux and sediment loads. Aquarium experiments with one or two crayfish were used to directly observe the relative impacts of crayfish activity and conspecific interactions on sediment suspension. Over the 28-day period, turbidity and suspended sediment exhibited a strong diel pattern, characterised by night-time increases in the frequency and magnitude of spikes in the turbidity data and by increases in ambient suspended sediment concentrations. Small diel fluctuations in stage were also measured, but the rises in stage were out of phase with turbidity and there was no correlation between stage and turbidity at any frequency. In the absence of a credible hydraulic explanation for the increases in night-time suspended sediment concentration, several lines of evidence, including results from the aquarium experiments, strongly suggest that crayfish are the most likely cause. We estimate that crayfish activity contributed at least $20 \%$ of the suspended sediment load over the 28-day period (which included two moderate floods) and this proportion was $47 \%$ during the days when baseflow conditions prevailed. This work extends and strengthens the argument that crayfish are important zoogeomorphic agents with potential implications for managing fine sediment pressures. It also highlights the need to better understand the link
\end{abstract}


between crayfish activity, sediment suspension and downstream dispersal, particularly the catchment-scale distribution and seasonality of such impacts.

\section{Patrones diarios del flujo de sedimento en suspensión y el efecto zoogeomórfico del cangrejo de río invasor}

RESUMEN. Este trabajo investiga la idea de que las actividades del cangrejo señal (Pacifastacus leniusculus) pueden aumentar los flujos de sedimento en suspensión en los ríos. Trabajos previos de campo, apoyados en experimentos, sugieren que la actividad nocturna del cangrejo puede aumentar la turbidez durante la noche, aunque tales datos de campo se limitan a un periodo de 16 horas en un solo sitio donde no existen series temporales de sedimento en suspensión. En este trabajo se han utilizado datos de campo recogidos durante un periodo de 28 días en el Brampton Branch del río Nene, Reino Unido, con el fin de cuantificar el impacto de las fluctuaciones diarias en la concentración de sedimento en suspensión. Se han empleado observaciones de campo y experimentos de laboratorio para evaluar la probabilidad de que los cangrejos, que son abundantes en este río, sean responsables de los patrones diarios. La turbidez fue medida a intervalos de 2 minutos en un único punto.El muestro de agua para la concentración de sedimento en suspensión se realizó en un ciclo diario y durante eventos tormentosos. La relación entre concentración de sedimento en suspensión y turbidez, junto con las series temporales de caudal, permitió el cálculo del flujo y la carga de sedimento. Los experimentos en acuario con uno o dos cangrejos fueron utilizados para observar directamente el impacto relativo de la actividad de los cangrejos. Durante el periodo de 28 días la turbidez y el sedimento en suspensión exhibieron un acusado patrón diario, caracterizado por aumentos nocturnos en la frecuencia y magnitud de los picos en la turbidez y por aumentos en la concentración de sedimento en suspensión. Se midieron también las pequeñas fluctuaciones, pero los incrementos estuvieron desfasados con la turbidez y no hubo relación entre turbidez y caudal a ningún nivel. En ausencia de explicación hidráulica creíble para los aumentos nocturnos de la concentración de sedimento en suspensión, varias líneas de evidencia, incluyendo los resultados de los experimentos en el acuario, sugieren consistentemente que los cangrejos son la causa más probable. Estimamos que la actividad de los cangrejos contribuye en al menos el $20 \%$ de la carga de sedimento en suspensión durante el periodo de 28 días (incluyendo dos crecidas moderadas), y esta proporción fue del $47 \%$ durante los días en que prevalecieron las condiciones de flujo de base. Este trabajo amplía y refuerza el argumento de que los cangrejos son importantes agentes zoogeomórficos. También subraya la necesidad de entender mejor las relaciones entre la actividad de los cangrejos, sedimentos en suspensión y su dispersión hacia aguas abajo, particularmente la distribución a escala de cuenca y la estacionalidad de tales impactos.

Key words: crayfish, ecosystem engineering, diurnal variability, fines, suspended sediment transport, turbidity, biogeomormorphology. 
Palabras clave: cangrejo de río, ingeniería de ecosistemas, variabilidad diurna, finos, transporte de sedimento en suspensión, turbidez, biogeomorfología.

Received 31 October 2013

Accepted 24 January 2014

*Corresponding author: Department of Geography, Loughborough University, United Kingdom. E-mail: s.rice@lboro.ac.uk

\section{Introduction}

Anthropogenic impacts on fine sediment dynamics in river networks associated with, for example, agriculture, forestry, damming and urbanisation are pervasive and problematic (Owens et al., 2005). Disruption of the fine sediment cascade has implications for the health of aquatic habitats (Wood and Armitage, 1997; Kemp et al., 2011), for siltation of navigation channels and reservoirs (Foster and Leys, 1999; Wang et al., 2005; Batalla, 2003) and for river channel morphodynamics (Sidorchuk and Golosov, 2003). These pressures require management of fine sediment dynamics based on an understanding of the key mechanisms and drivers. A pervasive assumption is that abiotic forcing entirely dominates fluvial sediment dynamics; that is, the interplay between suspension hydraulics and sediment availability controls fine sediment flux. However, numerous recent studies have suggested that river fauna might play a significant role in fluvial sediment dynamics by affecting sediment recruitment and transport processes (Harvey et al., 2011; Statzner, 2012; Rice et al. 2012). This paper investigates the possibility that fauna are relevant for understanding fluvial, fine sediment dynamics by examining the cumulative impact of a particular species, the signal crayfish (Pacifastacus leniusculus) on summertime sediment flux in a small, agricultural catchment in the United Kingdom.

The signal crayfish (Pacifastacus leniusculus) is established in Europe as a formidable invasive species that has had a deleterious impact on native fauna (Crawford et al., 2006). Signal crayfish are large (10-15 cm long), decapod crustaceans that have been measured at densities up to $15 \mathrm{~m}^{-2}$ in UK rivers (Peay, 2001). They burrow into river banks causing collapse where densities are high (Guan, 1994). Experiments by Johnson et al. (2010; 2011) extended work by Statzner et al. (2000, 2003) to demonstrate that signal crayfish dismantle the sedimentary structures that provide stability to gravel-bed river substrates, increasing entrainment rates and bedload transport. Some work also suggests that crayfish can affect fine, suspended sediment dynamics. Using enclosure experiments, Angeler et al. (2001) noted that bioturbation by red swamp crayfish (Procambarus Clarkii) substantially increased fine sediment suspension in a Spanish floodplain wetland and Creed and Reed (2004) observed reductions in the quantity of fine particulate matter (including inorganic fine sediment) in enclosures populated by the common crayfish (Cambarus bartonii) in headwater Appalachian streams. More recently, turbidity data collected at a site on the River Windrush, UK, over a 16-hour period in 2009 identified fine sediment suspension events during the hours of darkness in the absence of any hydraulic forcing. 
This site supports high densities of signal crayfish (Moorhouse and Macdonald, 2011), which are known to be nocturnal (Bubb et al., 2002; Johnson et al., 2014), suggesting that crayfish activity may have been responsible for the fine sediment entrainment (Harvey et al., 2014). Subsequent mesocosm experiments that investigated the links between crayfish nocturnalism, burrowing activity and sediment suspension, confirm that this argument is viable (Harvey et al., 2014).

In a review of the available evidence, Harvey et al. (2011; their Fig. 1) propose that crayfish may be important agents in catchment-scale sediment dynamics, with potentially important implications for fine sediment management at large scales. However, the paucity of available field data begs the question of how widespread and persistent any crayfish effect is. Moreover, if crayfish do increase sediment suspension at field scales, it is not clear whether there is a cumulative impact on downstream sediment fluxes or yield. The work reported in this paper is a response to Harvey et al. (2011) call for further research examining the role of crayfish in river geomorphology and aims to extend the work done to date by asking three questions:

1. Are nocturnal increases in turbidity and suspended sediment concentration apparent in another lowland UK river affected by crayfish and are they temporally persistent?

2. What evidence is there to support the argument that crayfish are responsible for any diel patterns?

3. What is the quantitative impact of any diel pattern in sediment suspension on local sediment flux and sediment yield?

Together these questions allow us to evaluate the hypothesis that signal crayfish can increase suspended sediment fluxes in rivers.

\section{Methods}

In the summer of 2012, measurements were made at a single site on the Brampton Branch of the River Nene in Northamptonshire, UK, which supports an abundant signal crayfish population. The work was carried out during the summer because this is the season when crayfish are most active. From approximately November until March the animals become relatively inactive probably in response to lower water temperatures and stronger flows, but during the warmer summer months they are more active (Bubb et al., 2002; Johnson et al., 2014). This means that the observations described here are seasonally biased toward identifying a crayfish impact, an intentional decision given the novelty of the investigation.

\subsection{Study reach}

The Brampton Branch is a small, mixed sand and gravel bed stream draining a catchment of approximately $160 \mathrm{~km}^{2}$. Mean annual rainfall averaged across the catchment is approximately $650 \mathrm{~mm}$. Mean flow, measured at the St Andrews gauging 
station, close to the catchment outlet (Ordnance Survey grid reference SP749613), is $1.13 \mathrm{~m}^{3} \mathrm{~s}^{-1}$, the $\mathrm{Q}_{10}\left(90^{\text {th }}\right.$ percentile) flow is $2.31 \mathrm{~m}^{3} \mathrm{~s}^{-1}$ and the $\mathrm{Q}_{1}$ flow is approximately $10 \mathrm{~m}^{3} \mathrm{~s}^{-1}$. Topography consists of gently undulating low hills and welldeveloped floodplains. Total relief across the catchment is $147 \mathrm{~m}$ and the mean drainage path slope is $0.043 \mathrm{~m} \mathrm{~m}^{-1}$. The dominant land use is arable farming (54\%), sheep and cattle grazing on grassland (28\%), some woodland (9\%) and no significant urban influence except in the lower reaches around the city of Northampton (4\%). The subsurface geology consists of mudstones and siltstones of Early to Middle Jurassic age that belong to the Whitby Mudstone Formation at lower elevations and the Northampton Sand Formation (berthierine-ooidal and sideritic ironstones) on the interfluves. Surficial deposits consist of alluvial floodplain and terrace sands and gravels along the stream valleys with some mid-Pleistocene tills on the interfluves.

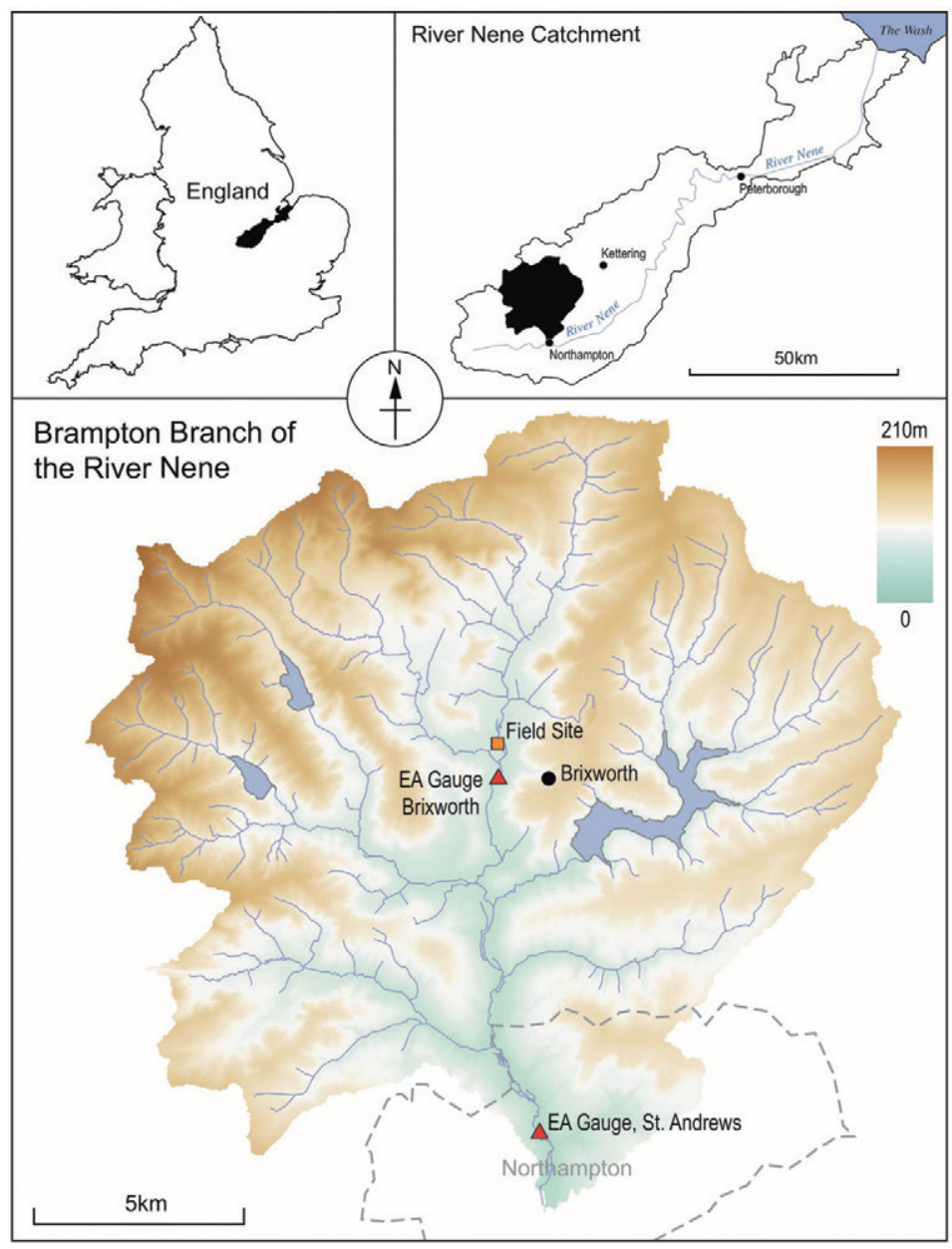

Figure 1. Location of the Brampton Branch of the River Nene showing the field site and location of the gauge used for discharge estimation. 
Monitoring focused on a single site near the village of Brixworth (SP736717; Fig. 1). Environment Agency sampling has persistently recorded the presence of signal crayfish at the site since 1998, although there is anecdotal evidence that they have been present since the late 1980s (Fig. 2). The stream channel is straight with a subtle pool-riffle structure and an average bed slope of 0.0006 . The channel cross section is approximately rectangular and $3.0 \mathrm{~m}$ wide (Fig. 2). The river bed consists of mixed sands and gravels and the banks are composed of fine-grained sands, silts and clay. A single subsurface bed material sample collected with a McNeil sampler and sieved at 1phi intervals, recorded a log-normal grain size distribution with: D16 $=0.3 \mathrm{~mm}, \mathrm{D} 50=$ $1.7 \mathrm{~mm}, \mathrm{D} 84=9.7 \mathrm{~mm}$ and $53.7 \%$ by mass finer than $2 \mathrm{~mm}$.
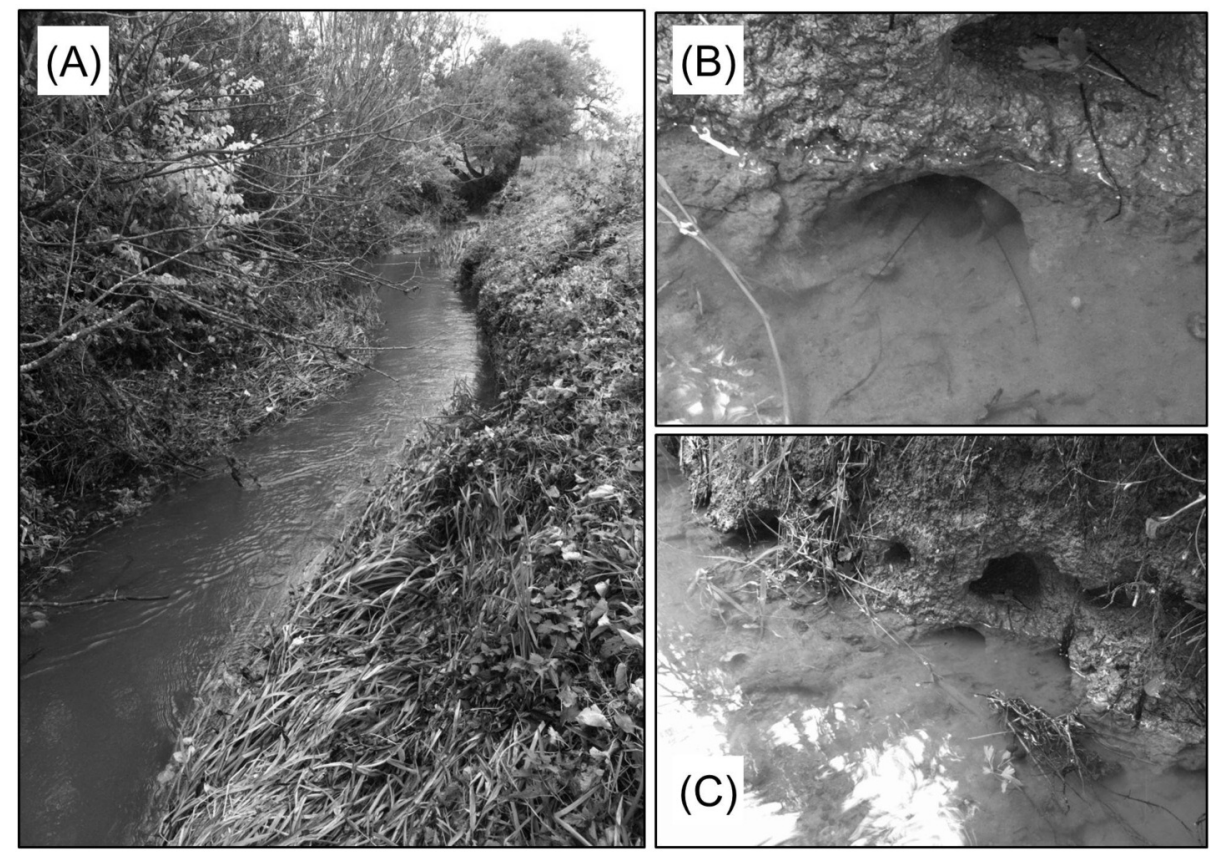

Figure 2. (A) The Brampton Branch of the Nene near Brixworth, immediately downstream of the monitoring site, looking downstream. Channel here is approximately $3 m$ wide.

(B) Signal crayfish emerging from an underwater burrow and $(C)$ evidence of extensive burrowing activity in the banks upstream of the monitoring site.

\subsection{Field measurements}

To address question 1, we measured turbidity at two-minute intervals between midnight on August $9^{\text {th }} / 10^{\text {th }}$ and midnight on September $6^{\text {th }} / 7^{\text {th }} 2012$. Turbidity was measured using a Greenspan TS1000 self-wiping turbidity sensor (ISO 7027) with a range from 0 to $1000 \mathrm{NTU}$ and quoted error of $\pm 3 \%$. The turbidity sensor was located $0.3 \mathrm{~m}$ from the right bank, approximately $0.1 \mathrm{~m}$ above the bed. A point measurement is assumed representative of the average cross-section turbidity based on our visual observations of excellent mixing across a range of flows. Water depth was measured as 
a proxy for entrainment hydraulics (also at 2 minute intervals), using an IML vented pressure transducer with a range of 0 to $5.0 \mathrm{~m}$ and quoted error of $\pm 0.05 \%$. The pressure transducer was mounted inside a vertical PVC pipe fitted to a support structure installed at the stream bank. The turbidity sensor was mounted inside an open, horizontal PVC pipe that was attached to the same structure. The sensor head was flush with the pipe orifice and the pipe was oriented downstream at approximately 30 degrees to the mean flow direction to minimise the risk of fouling by floating debris and weed.

An ISCO 6700 automated sampler was used to collect $1000 \mathrm{ml}$ river water samples via a hose inlet located immediately adjacent to the turbidity sensor. Two sampling programmes were used to collect water samples. First, from August $17^{\text {th }}$ until September $18^{\text {th }}$ samples were collected at midday and midnight (33 days, 66 samples) to provide corroborating evidence for any diel pattern in suspended sediment concentration (SSC) inferred from the turbidity measurements (question 1). These samples also provided 42 measurements (those coinciding with the period when the turbidity sensor was deployed) for use in calibrating measured turbidity to SSC. Second, a water level actuator was used to trigger sampling during a storm event on October $5^{\text {th }}$ and $6^{\text {th }} 2012$. Twenty-four samples were collected at 1-hour intervals to extend the range of SSC available for the calibration. The resulting power model calibration (Fig. 3) is significant (p $<<0.01$ ) and has an $R^{2}$ value of 0.93 :

$$
S S C=0.238 T u^{1.219}
$$

for SSC in $\mathrm{mg}^{-1}$ and $T u$ in NTU. The turbidity values used in the calibration range from 24 to 309 NTU. Measured turbidity values over the 28-day period ranged between 16 and 739 NTU, so the calibration is used to estimate SSC beyond its range. This is reasonable given the quality of the fit and the strong linearity in the log-log plot (Fig. 3).

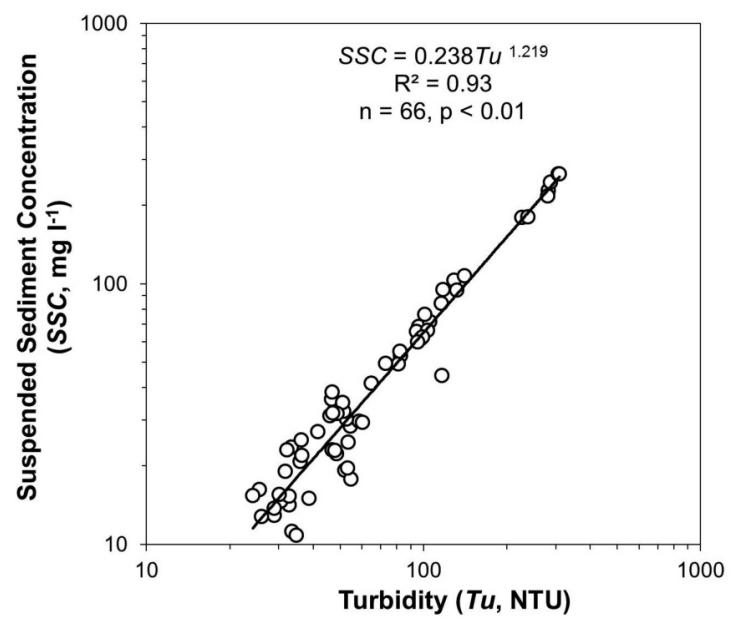

Figure 3. Relation between measured turbidity and concurrent suspended sediment concentration obtained by water sampling at the Brixworth site $(n=66)$. 
An Environment Agency gauge (Brixworth gauge) located approximately $1 \mathrm{~km}$ downstream of the monitoring site (SP737708) recorded discharge in 15-minute intervals $\left(Q_{\text {gauge }}\right)$. Between the monitoring site and gauge, a sewage treatment works (STW) and a single tributary add water to the Brampton Branch. In order to estimate discharge at the monitoring site $\left(Q_{B r i x}\right)$, these additions were estimated and subtracted from the gauge data. Outflow discharge data from the STW $\left(Q_{S T W}\right)$ were available for the same 15-minute intervals as the gauge measurements. Mean discharge from the STW is small $\left(0.012 \mathrm{~m}^{3} \mathrm{~s}^{-1}\right.$, standard deviation $\left.=0.008 \mathrm{~m}^{3} \mathrm{~s}^{-1}, \mathrm{n}=2689\right)$, and for individual 15-minute measurements contributes an average of $8.4 \%$ to the stream discharge. The tributary that enters the Brampton Branch downstream of the STW contributes $37.3 \%$ of the total drainage area at the confluence. The tributary catchment's land use, topography and hydrology are similar. A simple correction was therefore made by assuming that the Brampton Branch contributes $1-37.3=62.7 \%$ of the discharge measured at the gauge, after correction for the STW input. Discharges at the Brixworth monitoring site was then estimated as:

$$
Q_{\text {Brix }}=0.627\left(Q_{\text {gauge }}-Q_{\text {STW }}\right)
$$

To answer question 3, suspended sediment fluxes and loads were calculated for the 28-day period. A mean turbidity value for each fifteen-minute time interval of the discharge record was extracted from the 2-minute time series of turbidity measurements. Equation 1 was used to estimate the corresponding SSC (mg $\left.{ }^{-1}\right)$ and this result was used with the mean corrected discharge for the 15 minute period $\left(Q_{B r i x}\right.$, $\left.\mathrm{m}^{3} \mathrm{~s}^{-1}\right)$ to estimate mean sediment flux $\left(Q s=S S C \times Q_{\text {Brix }} \times 1000, \mathrm{mg} \mathrm{s}^{-1}\right)$ and suspended sediment load $\left(L_{15}=Q s \times 900 \times 10^{6}, \mathrm{~kg}\right)$ for each 15 minute interval.

\subsection{Laboratory experiments}

To help address question 2, an aquarium experiment was used to investigate how active crayfish affected fine sediment suspension. Bed material sediment recovered from the upper, exposed layer of the bed at the Brixworth site, was placed in a glass aquarium $(0.76 \times 0.3 \times 0.38 \mathrm{~m})$ with $0.25 \mathrm{~m}$ deep water. This material was fine grained consisting of mixed gravels, sands and silts with grain size characteristics similar to those of the McNeil sample described above. The river bed at Brixworth is poorly structured with no apparent armour layer, so the mixed sediment was simply placed in the aquarium with water from the site and allowed to settle. A turbidity sensor (Greenspan, non-wiping TS100, ISO 7027, 0-1000 NTU) was mounted inside the aquarium, $10 \mathrm{~cm}$ above the bed and programmed to measure turbidity at 10 second intervals. Both 10 second time-series' and 1 minute averages of this data are presented. A video camera was set up outside the aquarium and was used to record each experiment.

Three experimental runs were undertaken; two runs with one hour exposure to two crayfish (runs 1 and 2) and one with one hour exposure to one crayfish (run 3). Crayfish were captured from the Brixworth site and were $15 \mathrm{~cm}$ in total length, representing commonly caught, full-grown crayfish at the site. Each experimental run had three phases. Phase 1 lasted approximately 45 minutes prior to the addition of crayfish allowing turbidity prior to treatment to be monitored and acting as a control 
phase. Phase 2 followed immediately and consisted of one hour exposure to either one or two crayfish. After crayfish were removed, Phase 3 began and lasted 92 hours, monitoring the settling of fine sediment after disturbance by crayfish.

\section{Results}

\subsection{Temporal patterns of turbidity and water depth}

The two-minute turbidity time series shows substantial high-frequency variability, but the overall pattern, evidenced by the 3-hour mean series, is clear: there are strong diel fluctuations in water turbidity at Brixworth that persist throughout the 28-day period (Fig. 4). During two summer flood events (16:00 15th August to 00:00 17th August and 01:00 28th August to 00:00 1st September), turbidity responded as expected and increased beyond the levels measured during low-flow periods. In both cases there was a slight clockwise hysteresis, suggesting widespread sediment availability upstream of the site.

Outside of the two flood periods, stage measurements varied very little, between approximately 0.20 and $0.30 \mathrm{~m}$ (Fig. 5), but these data also show a strong diel tendency. Fig. 6 provides a detailed view of this pattern over five typical days (August $10^{\text {th }}$ to $\left.14^{\text {th }}\right)$ : depth consistently declined by 0.01 to $0.02 \mathrm{~m}$ between approximately noon and midnight each day, followed by no change or a slight rise of up to $0.01 \mathrm{~m}$ between midnight and noon. Between floods, this cycle is superimposed on a general decline in stage; approximately $0.03 \mathrm{~m}$ for these five days. For a number of reasons, discussed below, it is highly unlikely that this step-like pattern is responsible for the diel turbidity signal.

A persistent feature of the raw turbidity data is the presence of large, short-lived excursions from the mean trend, which often reflect a single 2-minute data point. To facilitate analysis, these spikes were defined as individual turbidity values that exceeded the local 3-hour mean by more than one global standard deviation (37.7 NTU; the standard deviation of the entire turbidity time series, excluding values measured during the two floods). Although the pattern is not consistent, there is clear evidence in Fig. 4 of an increase in the magnitude and number of turbidity spikes a night, which is reinforced by the diurnal pattern of 3-hour standard deviation values in Fig. 4B. A plot of mean spike magnitude $(M)$ and spike count $(P)$ for 12-hour nighttime (18:00 to $06: 00)$ and daytime (06:00 to 18:00) periods (Fig. 7) confirms that night time values tend to be higher. Fig. 7 excludes data from days affected by flooding, because otherwise flood timing would bias the result. For the non-flood data set shown in Fig. 6, the ratios $M_{n i g h t} / M_{d a y}$ and $P_{n i g h t} / P_{d a y}$ have mean values of 1.20 and $3.35(\mathrm{n}=20)$, respectively, which suggest that on average, spikes are more than three times more common at night and have a $20 \%$ higher magnitude. Significance testing confirmed that for the 21 non-flood days, mean spike count and mean spike magnitude are higher during night-time hours from 18:00 to 06:00 (1-tailed t-tests, $\mathrm{df}=39$ and 34, $\mathrm{p}=0.084$ and $\mathrm{p}=0.016$, respectively). 
(A)

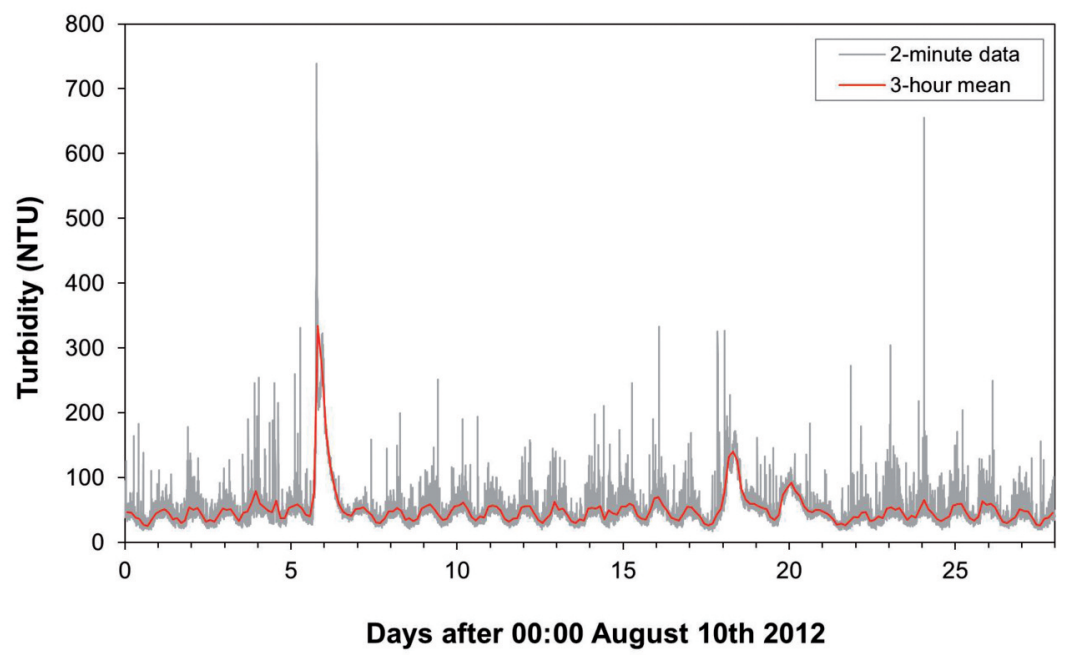

(B)

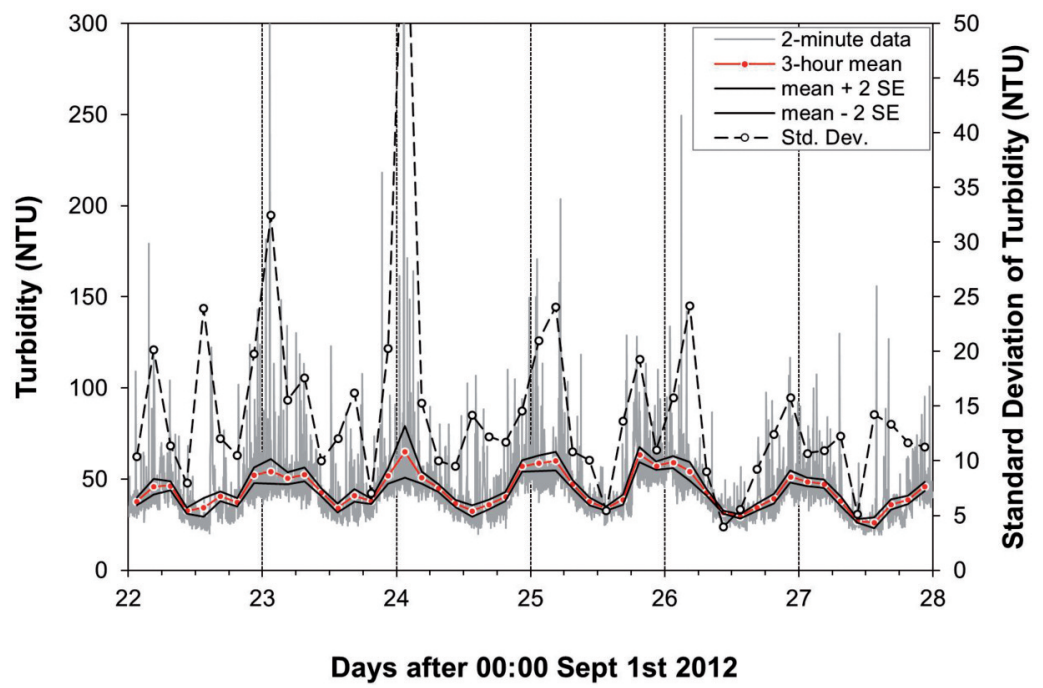

Figure 4. (a) Turbidity time series at the Brixworth monitoring site for the 28 days between August 10 and September 6, 2012. The grey line is 2-minute time-series and the red line connects 3-hour mean values. (B) Detail of the time-series for the final six days of monitoring showing the 2-minute time-series (grey line), 3-hour mean series (red line) with confidence bands (solid black lines) at \pm 2 standard errors and the corresponding standard deviation of the 3-hour series (dashed black line). Dotted vertical lines indicate midnight. 


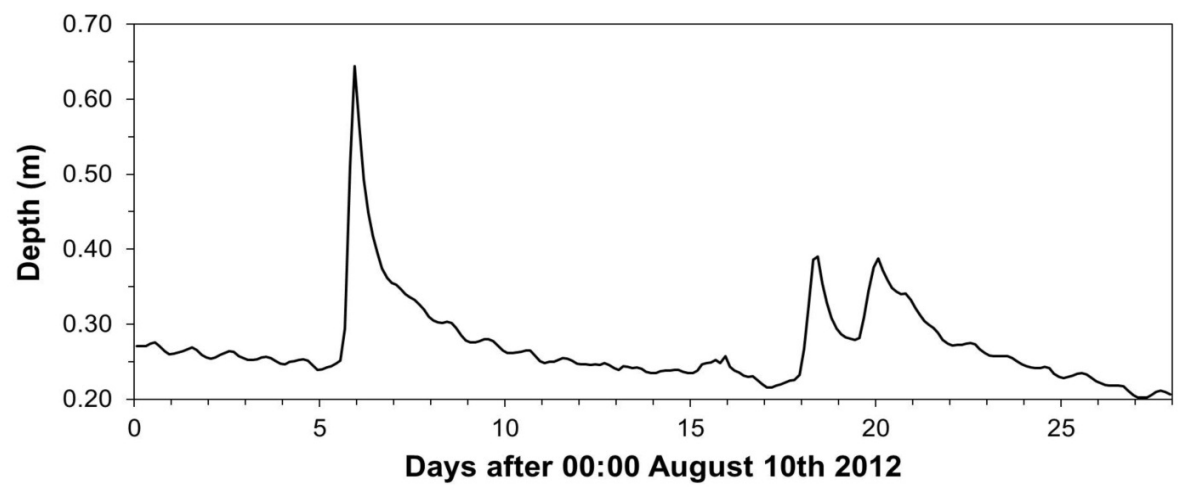

Figure 5. Water depth time series at the Brixworth monitoring site for the 28 days between August 10 and September 6, 2012.

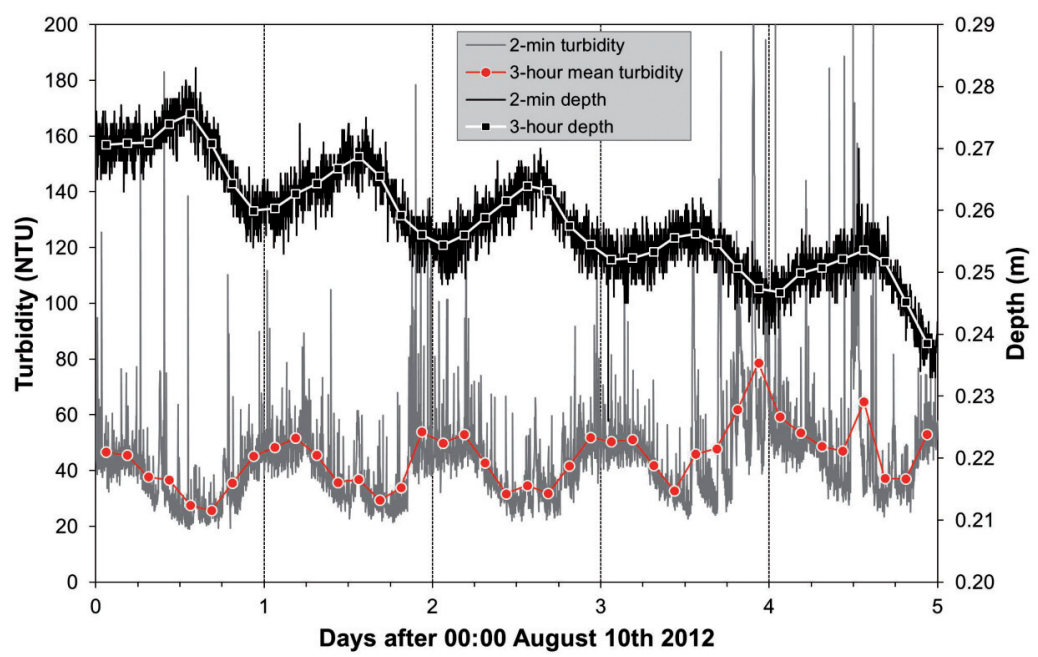

Figure 6. Detail of turbidity and water depth time series at the Brixworth monitoring site for the 28 days between August 10 and September 6, 2012. The grey line is the 2-minute turbidity data and the red line with circular symbols is the 3-hour mean turbidity series. The black line is the 2-minute depth data and the white line with square symbols is the 3-hour mean depth series.

\subsection{Suspended sediment sampling}

Water samples collected at midnight and at midday for a period of 33 days and analysed for suspended sediment concentration, confirmed that the diel pattern in measured turbidity was caused by night-time increases in suspended sediment concentration (Fig. 8). The mean value of SSC for samples collected at noon and at midnight was 19.04 and $31.90 \mathrm{mgl}^{-1}$, respectively; a significant difference (2-tailed, paired t-test, $\mathrm{df}=32, \mathrm{p}<0.001)$. 




Figure 7. Turbidity spike frequency and magnitude at the Brixworth monitoring site for the 28 days between August 10 and September 6, 2012. Magnitude data (circles) are calculated as average values for 12-hour night-time (18:00 to 06:00; filled circles) and daytime (06:00 to 18:00; open circles) periods. Frequency counts (squares) are for the same 12-hour periods: night-time (18:00 to 06:00; filled squares) and daytime (06:00 to 18:00; open squares).

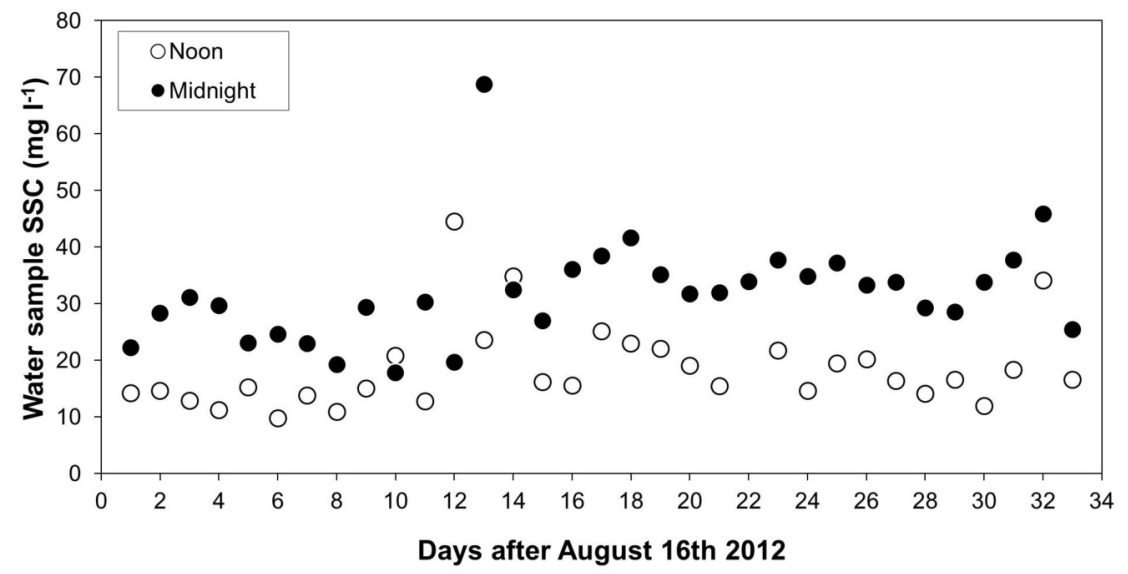

Figure 8. Suspended sediment concentration for water samples collected at noon (open circles) and at midnight (filled circles) for 33 days in August and September 2012, at the Brixworth monitoring site. 


\subsection{Suspended sediment fluxes and loads}

For the 28-day monitoring period, sediment fluxes and loads were estimated using the procedure described above. Average sediment flux at the monitoring site was $3.29 \mathrm{~g} \mathrm{~s}^{-1}$ and the maximum recorded value, which occurred during the first flood event, was $191.24 \mathrm{~g} \mathrm{~s}^{-1}$. During low flow periods, sediment flux varied on a diel cycle, peaking at between approximately 2 and $3 \mathrm{~g} \mathrm{~s}^{-1}$ at night and dropping to between approximately 0.8 and $1 \mathrm{~g} \mathrm{~s}^{-1}$ during the day. Sediment loads were calculated by integrating sediment fluxes. The total estimated sediment load was $7954.7 \mathrm{~kg}$ for the 28 days of monitoring, of which $4508.5 \mathrm{~kg}(57 \%)$ passed through the monitoring section during the two floods (evident on Fig. 4A and 5) and $3446.2 \mathrm{~kg}(43 \%)$ passed through the section during low flow conditions when the diel cycle was evident.

To estimate the impact of the diel cycle on sediment load, simple modelling was undertaken. It was assumed that, in the absence of the mechanism causing the night-time elevation of SSC (e.g. crayfish activity), turbidity would have reached a maximum value equal to that of the daytime minimum. Two synthetic turbidity time series were then constructed. In the first, which was for the entire 28 day period including flood events, measured NTU values were retained for the flood periods but the minimum daily turbidity value for a given non-flood day (from the 15 minute time series) replaced all of the values for that non-flood day. In the second, flood days were removed entirely to leave only the low-flow record and the minimum daily turbidity value for a given day replaced all of the values for that day. Sediment loads were calculated under these two "no diel cycle" scenarios and compared with the corresponding measured loads for the entire period and for the low-flow days, respectively (Table 1). The with-floods estimate is that night-time increases in SSC contributed $20 \%$ to the total yield and the low-flow estimate is that night time increases in SSC contributed $47 \%$ to the low-flow yield.

Table 1. Contribution of diel cycles to suspended sediment loads.

\begin{tabular}{|l|c|c|}
\hline \multirow{2}{*}{} & \multicolumn{2}{|c|}{ Suspended sediment load } \\
\cline { 2 - 3 } & Including flood days & Excluding flood days \\
\hline Measured, including diel cycles, kg & 7954.7 & 3446.2 \\
\hline "No diel cycle" modelling, kg & 6339.7 & 1831.2 \\
\hline Difference (due to diel cycles) kg & 1615.0 & 1615.0 \\
\hline Difference (due to diel cycles) \% & 20.3 & 46.9 \\
\hline
\end{tabular}

\subsection{Crayfish observations and experiment}

Turbidity in the aquaria prior to the introduction of crayfish was stable around values of 20,26 and 22 NTU for runs 1,2 and 3, respectively. After the addition of crayfish, turbidity increased substantially (Fig. 9). The 10-second time-series in all three runs is characterised by numerous, irregularly distributed spikes in turbidity with 
maximum measured turbidity values of 729,503 and 767 NTU, respectively. Spikes did not occur when crayfish were not present (i.e. during phases 1 and 3) and video recordings confirmed that spikes were associated with crayfish activity near the sensor. It was not possible to quantify the apparent correlation between activity and turbidity because the water quickly became too murky to see the crayfish.

In the first fifteen minutes of runs 1 and 2, with two crayfish, mean turbidity (averaged over 1 minute) increased from 20 to 134 NTU and from 26 to 120 NTU, respectively. As activity declined after an initial burst of exploration and fighting, so did the average turbidity (Fig. 9). However, in these two runs, turbidity was on average, six (6.09) and three and half (3.53) times higher when crayfish were present compared with the phase 1 control periods. After the crayfish were removed, turbidity slowly declined, but over the 92-hour period of phase 3, did not decline to pre-crayfish levels.

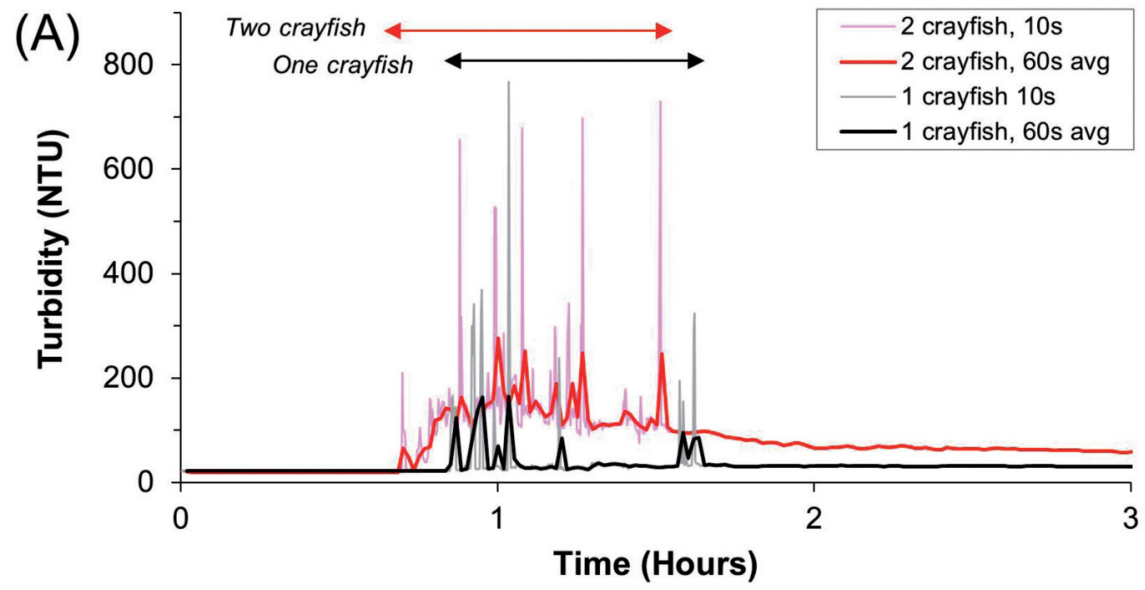

(B)
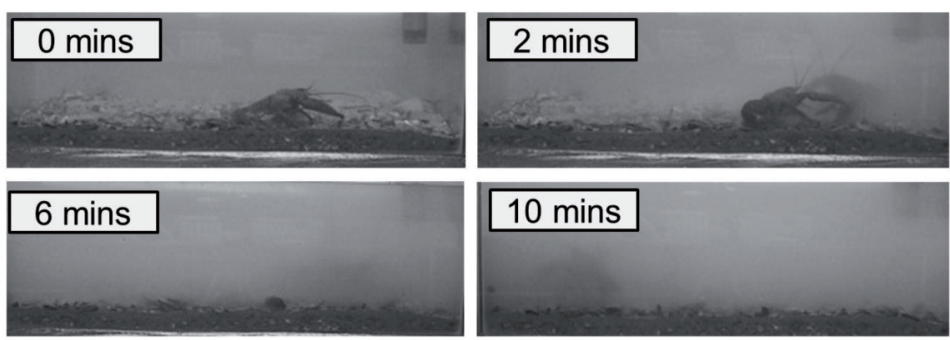

Figure 9. Laboratory aquarium experiments with crayfish on a substrate of Brixworth sediment. (A) Two separate experiments with a single crayfish and with two crayfish. The arrows indicate the periods during which crayfish were present. The grey line is a 10-second turbidity time series and the black line is a 60-second mean series during an experment with a single crayfish. The pink line is a 10-second turbidity time series and the red line is a 60-second mean series during an experment with two crayfish. (B) Video stills are from the experiment with two crayfish and are labelled with time since crayfish introduction. 
Turbidity increases were most affected by the fighting of crayfish and, consequently, two crayfish had a substantially greater impact on turbidity than a single crayfish. In run 3 , the single crayfish, was less active, remaining stationary for extended periods. However, digging and foraging did result in large turbidity spikes up to 767 NTU and 1-minute averages reached 164 NTU (Fig. 9). During the period of crayfish exposure, turbidity levels were on average two (2.03) times higher than during phase 1. In phase 3, turbidity dropped back to the pre-crayfish level of approximately 22 NTU after 48 hours, so the long-term effect was less persistent than when two crayfish were deployed, but was still substantial.

\section{Discussion}

A diel pattern of SSC persisted for at least 28 days during the Summer of 2012 on the crayfish-infested Brampton Branch of the River Nene. This suggests that the observation of an overnight increase in turbidity spikes recorded by Harvey et al. (2014) for a 16-hour period on the River Windrush, where there is also a significant population of signal crayfish, was not an isolated case and is indicative of a more widespread phenomenon.

\subsection{Causes of the diel patterns in stage and turbidity}

The diel pattern in low-flow stage (Fig. 4 and 5) was unexpected. Its explanation is less important herein than the question of whether it could be responsible for the observed variation in turbidity and SSC, but some consideration of possible causes is instructive. There are no licensed water discharges to the Brampton Arm above the study site except for a single STW at Draughton, approximately $6 \mathrm{~km}$ upstream, which adds water. However, the discharge from Draughton during the study period does not exhibit a diel pattern and pumped outflows rarely exceeded $0.006 \mathrm{~m}^{3} \mathrm{~s}^{-1}$, which is equivalent to a depth of approximately $0.005 \mathrm{~m}$ at Brixworth, less than the measured variation. It is possible that there is an unlicensed discharge to the river, but this would be very unusual. Third, it is possible that the diel pattern in depth is a natural phenomenon; for example, driven by summertime fluctuations in evapotranspiration in this catchment where arable crops, woodland and grassland make up $91 \%$ of the land cover. Such patterns have been widely observed (Burt, 1979; review in Grobovski et al., 2010) but most examples have only a short lag between peak evapotranspiration and minimal discharge, such that the diel cycle peaks in the early morning and is lowest in the late afternoon. This is not what was observed here, with stage maxima in the early afternoon and stage minima around midnight. However, Bond et al. (2002) have pointed out that the lag between peak vegetative water use and flow minimum can vary significantly as the strength of vegetation-streamflow coupling changes in response to seasonal shifts in soil water availability.

Whatever the cause of the stage fluctuation, it is unlikely that it be responsible for the daily fluctuation in turbidity and suspended sediment concentration. There are two principle mechanisms that might link stage and turbidity. First increased water 
depth could be associated with increased bed shear and turbulence sufficient to entrain and maintain suspension of a greater sediment load. One would then expect a strong positive correlation between stage and turbidity, but this is not apparent in the measured time series. Comparing the high frequency measurements in Fig. 6, it is clear that there is no correlation between the two signals, with spikes in turbidity that are unrelated to any concurrent increase in stage. When the diel periodicity in the 2-minute data series is removed, by subtracting respective 3-hour means from the corresponding data sequences, the Pearson correlation coefficient for the five days of data shown in Fig. 6 is $-0.027(\mathrm{n}=3600)$. This is not what one would expect if spikes in turbidity were being driven by short-term fluctuations in local hydraulics. Similarly, the phase shift in the low-frequency (3-hour) time series do not support this possibility because the peaks in stage are associated with turbidity minima when one would expect them to be associated with maxima (Fig. 6). In addition, the overall reductions in depth shown in detail in Fig. 6 and apparent between each of the flood periods in Fig. 5, are not associated with corresponding trends in turbidity, which one would expect if entrainment and suspension was being driven by small changes in water depth.

The second mechanism that might link stage and turbidity is a dilution effect. In particular, it is possible that the decrease in SSC observed during the day does not reflect an increase in sediment load, but is the result of the increased daytime flow volume acting on an unchanged sediment load. If this were the case, the ratio of two discharges from the time series would be the reciprocal of the ratios of SSC at the same two points in time:

$$
\left(\mathrm{Q}_{1} / \mathrm{Q}_{2}\right) /\left(\mathrm{SSC}_{2} / \mathrm{SSC}_{1}\right)=1
$$

Using the 15-minute time series of discharges and the equivalent SSC estimates, pairs of values were extracted for the fifteen minutes following midnight and noon for the days excluding flood events. Comparison of the resulting ratios $\left(\mathrm{Q}_{\text {midnight }} / \mathrm{Q}_{\text {noon }}\right.$ and $\mathrm{SSC}_{\text {noon }} / \mathrm{SSC}_{\text {midnight }}$ ) shows that the SSC ratios are substantially and consistently higher, so that the ratio in Equation 3 is, on average, 0.13. This confirms that the rises in nighttime SSC cannot be explained by a dilution effect.

In sum, the relations between depth and turbidity at minute to week timescales (Fig. 6) suggest that the turbidity signal is driven by a sediment supply or entrainment mechanism independent of stream flow, not by a hydraulic process. Crayfish activity is then a prime candidate for explaining the observed diel pattern in SSC.

Higher turbidity values at night are consistent with crayfish nocturnalism. Crayfish activity levels were not measured in the field during this period of monitoring, so we cannot demonstrate nocturnal behaviour patterns at this site, but numerous studies in similar UK settings have shown nocturnalism (Bubb et al., 2002), including our own observations on the River Bain in Lincolnshire (Johnson et al., 2014). With higher levels of activity at night, we would expect more burrow construction and 
maintenance activities, as well as a larger number of interactions between crayfish and the bed while foraging, fighting and fleeing from each other.

Like Harvey et al. (2014), we believe that individual turbidity spikes observed in the time-series correspond to the advection of sediment plumes generated by these crayfish activities and that the general night-time elevation of turbidity is the net effect of increases in the magnitude and frequency of the spikes (Fig. 7), especially the persistence of finer fraction suspension. To date, there is no direct field evidence tying crayfish activity to turbidity spikes, but during daylight hours, when crayfish were tempted out onto the substrate by bait, we observed them generating fine sediment plumes as they practised their defensive backward swimming manoeuvre. The aquarium experiments support these observations: the turbidity trace from the aquarium is very similar to those observed in the river with spikes in measured turbidity associated with entrainment events that were caused by crayfish movements. Both the turbidity spikes and the associated elevation of average turbidity could be qualitatively related to crayfish activity levels. Furthermore, the turbidity traces obtained in our aquarium experiments are qualitatively similar to those in the mesocosm experiments reported by Harvey et al. (2014) in which crayfish were directly observed to mobilise fine sediment when walking across the substrate and burrowing.

\subsection{The impact of diel cycles on sediment flux}

Comparison of observed sediment loads with modelled estimates for a "no diel cycle" scenario suggest that during base flow periods, night time SSC elevation is responsible for $47 \%$ of the measured load. This highlights the short-term, inter-flood significance of the diel cycling for sediment dynamics. If flood events are incorporated, night-time increases in SSC contributed $20 \%$ to the total yield, which provides a firstorder approximation of the potential long-term impact of the diel cycle on sediment load. It is likely that this approach overestimates the true ambient turbidity (i.e. the minimum values used to represent each day's turbidity level is too high), because the recorded daytime minima possibly reflect a residual effect of the previous night's elevation of SSC. In this case, these estimations of the diel effect are probably conservative. If crayfish are responsible for the diel pattern, and noting that the two floods were not trivial (exceedence probabilities of 10 and 30\%), this result suggests that crayfish can have an important effect on sediment mobility and suspended sediment loads both in the short term and over longer periods that incorporate flood activity.

Although we do not yet have data to investigate what the downstream effects of such a change in sediment flux are, it is possible to anticipate the likely controls on patterns of fine sediment dispersal and accumulation in streams with substantial crayfish populations. It is likely that four suites of factors are important. First, the degree of burrowing activity and extent of bank failure by which fines are recruited to the river bed. Second, the dispersal mechanics of the sediment entrained by crayfish, which is largely a function of ambient turbulence characteristics and the grain sizes 
entrained. Third, interactions between suspended sediment and downstream heterogeneities in morphology, vegetation, bed materials and hydraulics, that promote sediment sorting and deposition. Fourth, the distribution of crayfish along the reach, in terms of their density and location, which will determine the propensity for the reentrainment of accumulating sediment. Temporal variability is inherent in both the biotic and abiotic elements of this model, suggesting that there may be synoptic and seasonal variations in crayfish-induced fine sediment mobility.

\subsection{Biota and fluvial sediment systems}

Work on the interactions between plants, water and fine sediments is well established and a few studies have recognised invertebrate agents too (e.g. Wharton et al., 2006), but the bulk of zoogeomorphic and ecosystem engineering research in rivers has focused on salmonids and beaver (Gurnell, 1998; Butler and Malanson, 2005; Hassan et al., 2008). The work reported here therefore adds to a small but growing crop of evidence that points to the role of a wider group of biota in fluvial sediment dynamics (cf. Statzner, 2012; Rice et al., 2012). For example, similar diel turbidity cycles have been associated with nocturnal fish feeding in Georgia and Iowa, USA (Gillain, 2005; Loperfido et al., 2010). This growing body of evidence challenges the conventional view that abiotic drivers entirely dominate fluvial sediment transfer systems.

\section{Conclusions}

In relation to the three questions stated in the introduction, the following answers can be given based on the data collected from the Brampton Branch of the Nene in August-September 2012.

1. Diel, night time increases in turbidity and suspended sediment concentration, persisted for a 28-day period. This finding usefully extends the work of Harvey et al. (2014) by confirming that their overnight observation of a turbidity peak in the River Windrush was not an isolated case.

2. Numerous lines of evidence support the argument that heightened nocturnal crayfish activity was responsible for this pattern.

3. Crayfish activity contributed at least $20 \%$ of the suspended sediment load measured over the monitoring period that included two summer floods and this proportion was $47 \%$ during the days when base flow conditions prevailed. This is the first quantification of the possible impact of crayfish on suspended sediment fluxes and strongly suggests that their impact is not trivial. It adds to a very small set of published work quantifying biotic impacts on sediment fluxes in field settings (e.g. Hassan et al., 2008). 
Together, these conclusions suggest that where crayfish are present, impacts on fine sediment suspension are likely and strongly support the hypothesis that signal crayfish can increase suspended sediment fluxes in rivers.

In combination with other recent investigations (Harvey et al., 2014), this work extends and strengthens the argument that crayfish are important zoogeomorphic agents in at least some rivers, some of the time. However, neither the data presented here nor anywhere else provides comprehensive proof of the link between levels of crayfish activity and increases in turbidity in the field. Nor does this data or any other demonstrate the catchment-scale distribution and seasonality of such impacts and, crucially, whether there is a measureable cumulative impact on sediment yield at larger scales or over longer periods of time. Going forward, these are key issues that require attention before it is possible to properly address the implications of crayfish activities for managing fine sediment pressures (e.g. on phosphate dynamics, spawning habitat, benthic productivity, river bank erosion, channel dredging). Managing fine sediment in rivers requires robust understanding of all the relevant mechanisms and drivers. If crayfish are important agents in the fine sediment cascade, then a better understanding of their role could improve managers' ability to successfully target limited resources to sustainable and effective management solutions.

\section{References}

Angeler, D.G., Sánchez-Carrillo, S., García, G., Álvarez-Cobelas, M. 2001. The influence of Procambarus clarkia (Cambaridae, Decapoda) on water quality and sediment characteristics in a Spanish floodplain wetland. Hydrobiologia 464, 89-98.

Batalla, R.J. 2003. Sediment deficit in rivers caused by dams and instream gravel mining. A review with examples from NE Spain. Cuaternario y Geomorfología 17, 79-91.

Bond, B.J., Jones, J.A., Moore, G., Phillips, N., Post, D., McDonell, J.J. 2002. The zone of vegetation influence on baseflow revealed by diel patterns of streamflow and vegetation water use in a headwater basin. Hydrological Processes 16, 1671-1677.

Bubb, D.H., Lucas, M.C., Thom, T.J. 2002. Winter movements and activity of signal crayfish Pacifastacus leniusculus in an upland river, determined by radio telemetry. Hydrobiologia 483, 111-119.

Burt, T.P. 1979. Diurnal variations in stream discharge and throughflow during a period of low flow. Journal of Hydrology 41, 291-301

Butler, D.R., Malanson, G.P. 2005. The geomorphic influences of beaver dams and failures of beaver dams. Geomorphology 71, 48-60.

Creed, R.P., Reed, J.M. 2004. Ecosystem engineering by crayfish in a headwater stream community. Journal of the North American Benthological Society 23, 224-236.

Crawford, L., Yeomans, W.E., Adams, C.E. 2006. The impact of introduced signal crayfish Pacifastacus leniusculus on stream invertebrate communities. Aquatic Conservation: Marine and Freshwater Ecosystems 16, 611-621.

Foster, I.D.L., Lees, J.A. 1999. Changing headwater suspended sediment yields in the LOIS catchments over the last century: a paleolimnological, approach. Hydrological Processes 13, 1137-1153. 
Gillain, S. 2005. Diel turbidity fluctuations in streams in Gwinnett County, Georgia. In Proceedings of the 2005 Georgia Water Resources Conference, K.J. Hatcher (ed.), April 25-27, 2005, The University of Georgia, Athens, Georgia, USA.

Gribovski, Z., Zsilágyi, J., Kalicz, P. 2010. Diurnal fluctuations in shallow groundwater levels and streamflow rates and their interpretation - A review. Journal of Hydrology 385, 371-383.

Guan, R-Z. 1994. Burrowing behaviour of signal crayfish, Pacifastacus leniusculus (Dana), in the River Great Ouse, England. Freshwater Forum 4, 155-168.

Gurnell, A.M. 1998. The hydrogeomorphological effects of beaver dam-building activity. Progress in Physical Geography 22, 167-189.

Harvey, G., Moorhouse, T.P., Clifford, N.J., Henshaw, A., Johnson, M.F., MacDonald, D.W., Reid, I., Rice, S.P. 2011. Evaluating the role of invasive aquatic species as drivers of fine sedimentrelated river management problems: the case of the signal crayfish (Pacifastacus leniusculus). Progress in Physical Geography 35, 517-533.

Harvey, G., Henshaw, A., Moorhouse, T., Clifford, N., Holah, H., Grey, J., Macdonald, D. 2014. Invasive crayfish as drivers of fine sediment dynamics in rivers: field and laboratory evidence. Earth Surface Processes and Landforms 39, 259-271.

Hassan, M.A., Gottesfeld, A.S., Montgomery, D.R., Tunnicliffe, J.F., Clarke, G.K.C., Wynn, G., Jones-Cox, H., Poirier, R., MacIsaac, E., Herunter, H., Macdonald, S.J. 2008. Salmondriven bedload transport and bed morphology in mountain streams. Geophysical Research Letters 35, L0440, doi, 10.1029/2007GL032997.

Johnson, M.F., Rice, S.P., Reid, I. 2010. Topographic disturbance of subaqueous gravel substrates by signal crayfish (Pacifastacus leniusculus). Geomorphology 123, 269-278.

Johnson, M.F., Rice, S.P., Reid, I. 2011. Increase in coarse sediment transport associated with disturbance of gravel river beds by signal crayfish (Pacifastacus leniusculus). Earth Surface Processes and Landforms 36, 1680-1692.

Johnson, M.F., Rice, S.P., Reid, I. 2014. The activity of signal crayfish (Pacifastacus leniusculus) in relation to thermal and hydraulic dynamics of an alluvial stream. Hydrobiologia 724, 41-54

Kemp, P., Sear, D., Collins, A., Naden, P., Jones, I. 2011. The impacts of fine sediment on riverine fish. Hydrological Processes 25, 1800-1821.

Loperfido, J.V., Just, C.L., Papanicolaou, A.N., Schnoor, J.L. 2010. In situ sensing to understand diel turbidity cycles, suspended solids, and nutrient transport in Clear Creek, Iowa. Water Resources Research 46, W06525, doi:10.1029/2009WR008293.

Moorhouse, T.P., Macdonald, D.W. 2011. The effect of manual removal on movement distances in populations of signal crayfish (Pacifastacus leniusculus). Freshwater Biology 56, 2370-2377.

Owens, P.N., Batalla, R., Collins, A.J., Gomez, B., Hicks, D.M., Horowitz, A.J., Kondolf, G.M., Marden, M., Page, M.J., Peacock, D.H., Petticrew, E.L., Salomons, W., Trustrum, N.A. 2005. Fine-grained sediment in river systems: environmental significance and management issues. River Research and Applications 21, 693-717.

Peay, S. 2001. Eradication of Alien Crayfish Populations. Technical R\&D Report W1-037/TR. Environment Agency, Bristol, 116 pp.

Rice, S.P., Johnson, M.F., Reid, I. 2012 Animals and the Geomorphology of Gravel-bed Rivers. In Gravel-bed rivers: processes, tools, environments, M. Church, P. Biron, A.G. Roy (eds). John Wiley and Sons, Chichester, pp. 225-241.

Sidorchuk, A.Y., Golosov, V.N. 2003. Erosion and sedimentation on the Russian Plain, II: the history of erosion and sedimentation during the period of intensive agriculture. Hydrological Processes 17, 3347-3358.

Statzner, B., Fievet, E., Champagne, J-Y., Morel, R., Herouin, E. 2000. Crayfish as geomorphic agents and ecosystem engineers: biological behaviour affects sand and gravel erosion in experimental streams. Limnology and Oceanography 45, 1030-1040. 
Statzner, B., Peltret, O., Tomanova, S. 2003. Crayfish as geomorphic agents and ecosystem engineers: effect of a biomass gradient on baseflow and flood-induced transport of gravel and sand in experimental streams. Freshwater Biology 48, 147-163.

Statzner, B. 2012. Geomorphological implications of engineering bed sediments by lotic animals. Geomorphology 157-158, 49-65.

Wang, G.Q., Wu, B. S., Wang, Z-Y. 2005. Sedimentation problems and management strategies of Sanmenxia Reservoir, Yellow River, China. Water Resources Research 41, W09417, 17.10.1029/2004WR003919.

Wharton, G., Cotton, J.A., Wotton, R.S., Bass, J. A. B., Heppell, C. M., Trimmer, M., Sanders, I. A., Warren, L.L. 2006. Macrophytes and suspension-feeding invertebrates modify flows and fine sediments in the Frome and Piddle catchments, Dorset (UK). Journal of Hydrology 330, 171-184.

Wood, P.J., Armitage, P.D. 1997. Biological effects of fine sediment in the lotic environment. Environmental Management 21, 203-217. 